\title{
The Effect of Inflation and Financial Deepening on Output Growth: A Cointegration and ECM Approach for Nigeria
}

\author{
${ }^{1}$ Fasoranti M. M., Ph.D and ${ }^{*}{ }^{2}$ R. Santos Alimi \\ ${ }^{1,2}$ Economics Department, AdekunleAjasin University, Ondo State, Akungba-Akoko, Nigeria.
}

\begin{abstract}
This study aimed at empirically exploring the triangle of relationships - finance-inflation-growth with the broader data sets (1970 - 2012) to see whether a direct effect of inflation on growth can be identified as well as an indirect effect through financial sector development. Italso seeks toexplore the relative strength of the variables in affecting economicgrowth using the variance decompositions (VDCs) and the impulse-response functions (IRFs) based on the structural vector autoregression(VAR) framework. We found that both Engel Granger and Johansen cointegration test suggest that the variables are cointegrated. Based on the existence of cointegration relationship among the variables, we therefore estimate the long-run relationships using the Stock-Watson's dynamic ordinary least squares (DOLS) model. The results of DOLS model give an indication that inflation effect on growth is independent of financial development while the financial development effect on growth is dependent of inflation. Furthermore, we also found no evidence of short run causality between RGDP and INF; and there is existence of short run interaction between RGDP and FD that is a bi-directional causality between the variables. Variance decompositions (VDCs) results revealed the variations in the economic growth in Nigeria respond more to shocks in trade openness and next government spending, however, the variations in the economic growth rely more on its own innovations. The policy implication of this finding is for policy makers to develop strategy that will holistic reforms in the financial system and enhance stock market development along side with banking financial institutions. Finally, since financial development effect on growth is dependent of inflation, policy that will ensure price stability will promote output further.
\end{abstract}

Keywords: Inflation, Financial Development, Output Growth, VECM

JEL Classifications: D53, E31, G29

\section{Introduction}

The role of financial institutions in economic growth has attracted the attention of researchers and policymakers in recent times. There is a large body of literature, both empirical and theoretical, which have examined this issue. The findings of these studies have been controversial. While some studies find that financial sector development has been instrumental in accelerating economic growth, others have suggested that it has not been very significant. Levine (2005) and Beck (2009) for instance, argued that the positive effect of financial development on economic growth can be explained by five mechanisms, whose operations reduce the negative impact of information asymmetries among economic agents and the transaction costs involved in their activities. According to them, financial system provides means of payments that facilitates a greater number of transactions'; concentrates the savings of a large number of investors; makes possible the allocation of resources to their most productive economic use through effective evaluation and monitoring of investment projects; improves corporate governance; and contributes to risk management.Evidence abounds that there is a relationship between finance and economic growth but the direction of causality has remained the bone of contention. In summary, three schools of thought are identifiable in the extant literature: (i) supply-leading response school of thought which argues that financial development leads to economic growth pioneered by Schumpeter (1911) and confirmed by notable studies such as Levine et al. (2000), Chang and Caudill (2005), Wadud (2005)and Bittencourt (2012); (ii) demand-leading school of thought supported by studies such as Odhiambo (2004), Liang and Teng (2006), Zang and Kim (2007),Hurlin and Venet (2008), Odeniran, and Udeaja, (2010),Blanco (2009) and Waqabaca (2004), which argues that growth leads to financial development; (iii) bidirectional school of thought grounded by the studies such as Wood (1993), Akinboade (1998), Luintel and Khan (1999), Unalmis (2002), Rousseau and Vuthipadadorn (2005), Apergis et al. (2007) and Odeniran, S. O. and Udeaja, E.A (2012) which submits that there is a bidirectional causality between financial development and economic growth.

Nigeria has an interesting history of finance sector reforms such as recapitalization, mergers and acquisition, capital controls and deflationary policies which have taken place since 2004. There are few studies on relationship between financial sector development and economic growth. Okwo et al (2012) examined the effect as well as the causal relationship between financial sector development and economic growth in Nigeria and their findings suggested thatthe measures of financial development showed negative relationships with economic growth. Torruam et al (2013) investigated the causal relationship between financial deepening and 
Economic Growth in Nigeria and found from Granger-causality that there is unidirectional causality running from economic growth to financial deepening. This implies thatdeveloping the financial sector in Nigeria improves financial structures and ensures efficient delivery of financial services to the private sector to invest and subsequently attract more private sector participation for increase output.Adam (2011) examined how efficient the financial intermediation process has been in Nigeria's growth performance. The study employed the 2SLS approach. The empirical results showed that financial intermediation process is sub-optimal and caused by high lending rate, high inflation rate, low per capita income, and poor branch networking. Saibu, Nwosa, and Agbeluyi, (2011) examined effects of financial development and foreign direct investment on economic growth in Nigeria. The results showed that financial development and foreign direct investment had negative effects on economic growth in Nigeria. The result also showed that financial market liquidity and not the size of the financial market matter for economic growth in Nigeria.

The remainder of this paper has the following structure: Section 2 describes the data set used. Section 3 explains the methodological framework and reports the results in section 4. Section 5 concludes the paper: it summarises the importance of the results and their implications in terms of policy.

\section{Data and Model}

The study used macroeconomic series that consist of yearly observations between 1970 and 2012. The study estimated the following model for Nigeria;

$\operatorname{lnRGDP}_{\mathrm{t}}=\delta+\gamma_{1} \operatorname{lnRGDP} P_{\mathrm{t}-1}+\gamma_{2} \mathrm{INF}_{\mathrm{t}}+\gamma_{3} \ln \ln _{\mathrm{t}}+\gamma_{4} \operatorname{lnGOV}_{\mathrm{t}}+\gamma_{5} \ln \mathrm{TOP}_{\mathrm{t}}+\mu_{\mathrm{t}}$ $\mu$ is error term

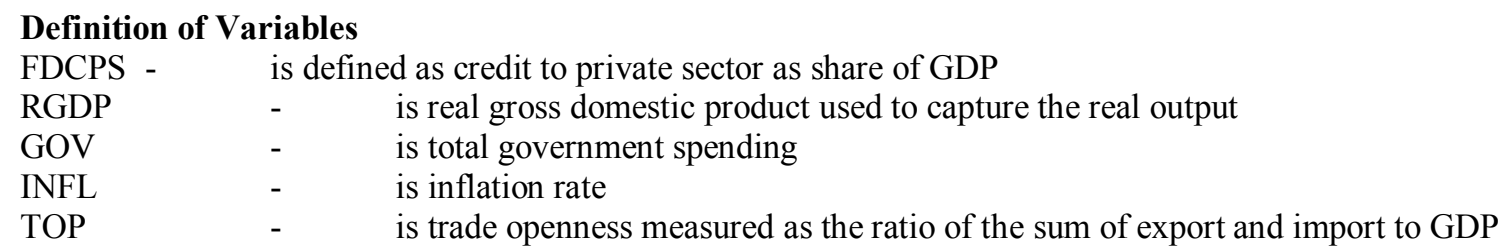

The study included two macroeconomic control variables (CV): trade openness (TOP) and government expenditure (GOV) to avoid simultaneous bias (Gujarati, 2006) in the regressions. We use the natural log of the variables except for inflation, because natural logarithm of a series effectively linearizes the exponential trend (if any) in the time series data since the log function is the inverse of an exponential function (Asteriou and Price, 2007). Moreover, opting for log of the variables may prevent cumbersomeness in the modelling and inference and it allows the regression coefficients to be interpreted as elasticity (Rahaman and Salahuddin, 2010). Annual data of all variables have been collected from World Bank, and International Financial Statistics (IFS) and CBN Statistical Bulletin

\section{Methodological Framework}

Unity Root and Cointegration Tests

In this study, the empirical investigation consists of three main steps. First, we examined the stationarity of our variables. A non-stationary time series has a different mean at different points in time, and its variance increases with the sample size (Harris and Sollis (2003). A characteristic of non-stationarity of time series is very crucial in the sense that the linear combinations of these time series make spurious regression. In the case of spurious regression, $t$-values of the coefficients are highly significant, coefficient of determination $\left(\mathrm{R}^{2}\right)$ is very close to one and the Durbin Watson (DW) statistic value is very low, which often lead investigators to commit a high frequency of Type 1 errors (Granger and Newbold, 1974). In that case, the results of the estimation of the coefficient became biased. Therefore it is necessary to detect the existence of stationarity or non-stationarity in the series to avoid spurious regression. For this, the unit root tests are conducted using DFGLS, and Ng-Perron. If a unit root is detected for more than one variable, we further conduct the test for cointegration to determine whether we should use Error Correction Mechanism (ECM).

Secondly, cointegration tests were conducted to see if there is a long-run or equilibrium relationship between the variables. Two popular cointegration tests, namely, the Engel-Granger (EG) test and the Johansen test are used. The EG test is contained in Engel and Granger (1987) while the Johansen test is found in Johansen (1988) and Johansen and Juselius (1990). The EG test involves testing for stationarity of the residuals. If the residuals are stationary at level, it implies that the variables under consideration are cointegrated. The EG approach could exhibit some degree of bias arising from the stationarity test of the residuals from the chosen equation. As pointed out by Idowu (2005), the EG test assumes one cointegrating vector in systems with more than two variables and it assumes arbitrary normalization of the cointegrating vector. Besides, the EG test is not very powerful and robust when compared with the Johansen cointegration test. Thus, it is necessary to complement the EG test with the Johansen test. 


\section{Short Run Dynamics within ECM Framework}

Granger (1988) demonstrates that causal relations among variables can be examined within the framework of ECM, with cointegrated variables. While the short run dynamics are captured by the individual coefficients of the lagged terms, the error correction term (ECT) contains the information of long run causality. Significance of lagged explanatory variable depicts short run causality while a negative and statistical significant ECT is assumed to signify long run causality (Bannerjee and Newman, 1998). We specify the error correction term as follows;

$$
\begin{aligned}
& \operatorname{lnRGDP}_{\mathrm{t}}=\delta+\gamma_{1} \operatorname{lnRGDP}_{\mathrm{t}-1}+\gamma_{2} \mathrm{INF}_{\mathrm{t}}+\gamma_{3} \operatorname{lnFD}_{\mathrm{t}}+\gamma_{4} \operatorname{lnGOV}_{\mathrm{t}}+\gamma_{5} \operatorname{lnTOP} \mathrm{P}_{\mathrm{t}}+\mu_{\mathrm{t}} \\
& \quad \text { (from equation 1) } \\
& \mu_{\mathrm{t}}=\operatorname{lnRGDP} \mathrm{P}_{\mathrm{t}}-\delta-\gamma_{1} \operatorname{lnRGDP}_{\mathrm{t}-1}-\gamma_{2} \mathrm{INF}_{\mathrm{t}}-\gamma_{3} \operatorname{lnRGDP}_{\mathrm{t}}-\gamma_{4} \operatorname{lnGOV}_{\mathrm{t}}-\gamma_{5} \ln \operatorname{lnOP}_{\mathrm{t}}
\end{aligned}
$$

where $\mu_{t}$ is the residual term and $\gamma$ is a cointegrating coefficient. From equation (5), we can formulate a simple ECM as:

$\Delta \operatorname{lnRGDP}{ }_{t}=\varphi_{1}+\varphi_{2} \Delta \operatorname{lnRGDP}_{\mathrm{t}-1}+\varphi_{3} \Delta \mathrm{INF}_{\mathrm{t}}+\varphi_{4} \Delta \operatorname{lnFDCPS}_{\mathrm{t}}+\varphi_{5} \Delta \operatorname{lnGOV}_{\mathrm{t}}+\varphi_{6} \Delta \ln _{\mathrm{n}} \mathrm{OP}_{\mathrm{t}}+\Omega \mu_{\mathrm{t}-1}+v_{\mathrm{t}}$

Specifically from the ECM expressed in equation (6), $\varphi$ captures any immediate, short term or contemporaneous effect that the explanatory variables have on the financial variable. The coefficient $\gamma_{\mathrm{i}}$ reflects the long-run equilibrium effect of INF, RGDP, FD and TOP on RGDP and the absolute value of $\Omega$ decides how quickly the equilibrium is restored. We can therefore say that $\lambda_{\mathrm{i}}$ and $\Omega$ are the short-run parameters while $\varphi_{\mathrm{i}}$ is the long-run parameter.

\section{Variance Decompositions (VDCs) and Impulse-Response Functions (IRFs)}

Apart from the above battery of time series techniques, the study also generate variance decompositions (VDCs) and impulse-response functions (IRFs) to further delve into the dynamics of interaction among our variables of interest. The VDCs enable us to examine the out-of sample causality among the variables in the VAR system. It measures the percentage of the forecast error of variable that is explained by another variable. Precisely, it indicates the relative impact that one variable has on another variable. At the same time, it provides information on how a variable of interest responds to shocks or innovations in other variables. Thus, in our context, it allows us to explore the relative importance of financial development and inflation in accounting for variations in economic growth. To interpret economic implications from VDCs findings, the Sim's (1980) innovation accounting procedure is employed. This procedure involves the decomposition of forecast error variance of each variable into components attributable to its own innovations and to shocks of other variables in the system. On the other hand, the IRFs (also known as innovation accounting in the literature) allow us to trace temporal responses of variables to its own shocks and shocks in other variables. In our context, from the IRFs we can assess the direction, magnitude and persistent of economic growth responses to innovations in the financial development and inflation. Finally, following Narayan and Smyth (2005), we test for parameter stability of the long-run parameters together with the short-run movements for the equations. (Abd.Majid, 2007).

\section{Unit Root Test}

\section{Empirical Results and Discussion}

In order to examine the integrating level of variables, standard tests like DF-GLS, and Ng-Perronwere employed. Mostly in the literature to find out the order of integration ADF (Dicky\& Fuller, 1979) and PP (Philip \&Perron, 1988) tests have been used extensively. Due to their poor size and power properties, both tests are not reliable for small sample data set (Dejong et al, 1992 and Harris and Sollis, 2003). These tests seem to overreject the null hypotheses when it is true and accept it when it is false. While newly proposed tests such as

\begin{tabular}{|c|c|c|c|c|}
\hline \multicolumn{5}{|c|}{ Table 1. DF-GLS \& Ng-Perron Unit Root Test } \\
\hline Variables & \multicolumn{2}{|l|}{ DF-GLS at level } & \multicolumn{2}{|l|}{ DF-GLS at first difference } \\
\hline $\operatorname{lnRGDP}$ & \multicolumn{2}{|l|}{-0.234997} & \multicolumn{2}{|l|}{$-6.098889^{\mathrm{a}}$} \\
\hline $\operatorname{lnGOV}$ & \multicolumn{2}{|l|}{1.269989} & \multicolumn{2}{|l|}{$-7.549572^{a}$} \\
\hline INF & \multicolumn{2}{|l|}{$-3.247812^{\mathrm{a}}$} & \multicolumn{2}{|l|}{-} \\
\hline $\operatorname{lnTOP}$ & \multicolumn{2}{|l|}{-0.18519} & \multicolumn{2}{|l|}{$-6.260638^{a}$} \\
\hline $\operatorname{lnFD}$ & \multicolumn{2}{|l|}{-0.875320} & \multicolumn{2}{|l|}{$-5.503878^{a}$} \\
\hline \multicolumn{5}{|c|}{ Ng-Perron at level } \\
\hline & $\mathrm{MZa}$ & $\mathrm{MZt}$ & MSB & MPT \\
\hline $\operatorname{lnRGDP}$ & 0.37870 & 0.31650 & 0.83575 & 44.6801 \\
\hline $\operatorname{lnGOV}$ & 1.45987 & 2.00951 & 1.376650 & 137.505 \\
\hline
\end{tabular}
Dicky-Fuller generalized least square (DF-GLS) de-trending test developed by Elliot et al. (1996) and NgPerron test following Ng-Perron (2001) seem to solve this arising problem. 
The Effect of Inflation and Financial Deepening on Output Growth: A Cointegration and ECM

\begin{tabular}{|c|c|c|c|c|}
\hline INF & $-13.6711^{b}$ & -2.61089 & 0.19098 & 1.80598 \\
\hline $\operatorname{lnTOP}$ & 0.09432 & 0.05735 & 0.60805 & 25.4304 \\
\hline FD & -2.15737 & -0.68962 & 8.82966 & \\
\hline \multicolumn{5}{|c|}{ Ng-Perron at first difference } \\
\hline & $\mathrm{MZa}$ & $\mathrm{MZt}$ & MSB & MPT \\
\hline lnRGDP & $-20.4732^{\mathrm{a}}$ & -3.19861 & 0.15623 & 1.19973 \\
\hline $\operatorname{lnGOV}$ & $-19.8249^{\mathrm{a}}$ & -3.13378 & 0.15807 & 1.28770 \\
\hline INF & - & - & - & - \\
\hline $\operatorname{lnTOP}$ & $-20.4746^{\mathrm{a}}$ & -3.19095 & 0.15585 & 1.22696 \\
\hline $\operatorname{lnFD}$ & $-20.0654^{\mathrm{a}}$ & -3.16138 & 0.15755 & 1.24246 \\
\hline
\end{tabular}

The unit root results reported in Table 1 showed that all the series, except inflation, are non-stationary at level but become stationary after taking their first difference i.e. I(1). Thus we apply the Engel - Granger cointegration to test long run relationship between the variables. Following the modeling approach described earlier, we determine the appropriate lag length and conducted the cointegration test.

\begin{tabular}{l|l|l|l|l|l|}
\hline \multicolumn{7}{|c|}{ Table 2: Lag Length Selection } \\
\hline Lag & LR & FPE & AIC & SC & HQ \\
\hline 0 & NA & $9.01 \mathrm{e}-06$ & 5.409483 & 5.665415 & 5.501309 \\
\hline 1 & $318.4992^{*}$ & $2.78 \mathrm{e}-09^{*}$ & $-2.697463^{*}$ & $-0905935^{*}$ & $-2.054678^{*}$ \\
\hline 2 & 32.43978 & $5.79 \mathrm{e}-09$ & -2.098993 & 1.228130 & -0.905250 \\
\hline 3 & 30.20399 & $1.19 \mathrm{e}-08$ & -1.763039 & 3.099680 & -0.018337 \\
\hline 4 & 26.81656 & -1.832353 & 4.565961 & 0.463307 \\
\hline *indicates lag order selected by the criterion & & \\
LR: sequential modified LR test statistics (each test at 5\% level) & \\
FPE: Final Prediction Error \\
AIC: Akaike Information Criterion \\
SC: Schwarz Information Criterion \\
HQ: Hannan-Quinn Information Criterion
\end{tabular}

Table 2 reports the optimal lag length of one out of a maximum of 4 lag lengths as selected by the five criterions. The EG test presented in table 3showed that the series in our modelis stationary at level under Augmented Dickey-Fuller (ADF), Philip-Perron (PP) and KPSS unit root tests. Therefore, the Engel - Granger cointegration test suggests that the variables are cointegrated.

\begin{tabular}{|l|l|l|l|l|l|}
\hline \multicolumn{5}{|c|}{ Table 3: Stationarity Test of the Residual } \\
\hline & Variable & ADF & PP & KPSS & $\begin{array}{l}\text { Order of } \\
\text { Integration }\end{array}$ \\
\hline & Residual & $\begin{array}{l}-5.639084^{* * *} \\
(0.0000)\end{array}$ & $\begin{array}{l}-5.678036^{* * *} \\
(0.0978)\end{array}$ & 0.106819 & $\mathrm{I}(0)$ \\
\hline
\end{tabular}

To complement the EG test, the Johansen test was conducted and reported in Tables 4. Table 4 provided the results from the application of Johansen cointegration test among the data set. The results are based on the assumptions of linear deterministic trend and lag interval in first difference of 1 to 1 . Trace test rejected the null hypothesis of no cointegration at both 10 percent significance levelwhile maximum eigenvalue do not reject the null hypothesis of no cointegration at the same level of significance.

\begin{tabular}{|c|c|c|c|c|}
\hline \multicolumn{5}{|c|}{ Table 4: Result of Johansen Cointegration Test } \\
\hline & \multirow[t]{2}{*}{ Null Hypothesis } & \multirow{2}{*}{$\begin{array}{l}0.05 \text { Critical } \\
\text { Values }\end{array}$} & \multirow[b]{2}{*}{ Test Statistics } & \multirow[b]{2}{*}{ Prob. Value } \\
\hline & & & & \\
\hline Lags & & & 1 & \\
\hline \multirow{2}{*}{$\begin{array}{l}\text { Trace } \\
\text { Statistics }\end{array}$} & $\mathrm{r}=0$ & 69.8188 & 67.9398 & 0.0699 \\
\hline & $\mathrm{r}=1$ & 47.8561 & 37.2652 & 0.3351 \\
\hline \multirow{2}{*}{$\begin{array}{l}\text { Max-Eigen } \\
\text { Statistics } \\
\end{array}$} & $\mathrm{r}=0$ & 33.8768 & 30.6745 & 0.1151 \\
\hline & $\mathrm{r} \leq 1$ & 27.5843 & 15.7849 & 0.6839 \\
\hline Trace & No of Vectors & & 1 & \\
\hline Max-Eigen & No of Vectors & & 0 & \\
\hline
\end{tabular}

Based on the existence of cointegration relationship among the variables, we therefore estimate the long-run relationships using the Stock-Watson's dynamic ordinary least squares (DOLS) model. The presence of leads and lags for different variables eliminates the bias of simultaneity within a sample and DOLS estimates 
and provide better approach to normaldistribution. DOLS model with dependent variable $\mathrm{y}_{\mathrm{t}}$ and independent variable $\mathrm{x}_{\mathrm{t}}$ is specified as below:

$$
\mathrm{y}_{\mathrm{t}}=\phi_{0}+\phi_{1} \mathrm{x}_{\mathrm{t}}+\sum_{\mathrm{j}=-\mathrm{m}}^{\mathrm{n}} \mathrm{d} \Delta \mathrm{x}_{\mathrm{t}-\mathrm{j}}+\varepsilon_{\mathrm{t}}
$$

Where $\mathrm{n}$ and $\mathrm{m}$ show lag and lead length, and $\phi$ indicates the long run effect of a change in $\mathrm{x}$ on $\mathrm{y}$. The reason why lag and lead terms are included in DOLS model is that they have the role to make its stochastic error term independent of all past innovations in stochastic repressors (Baba et al, 1992).

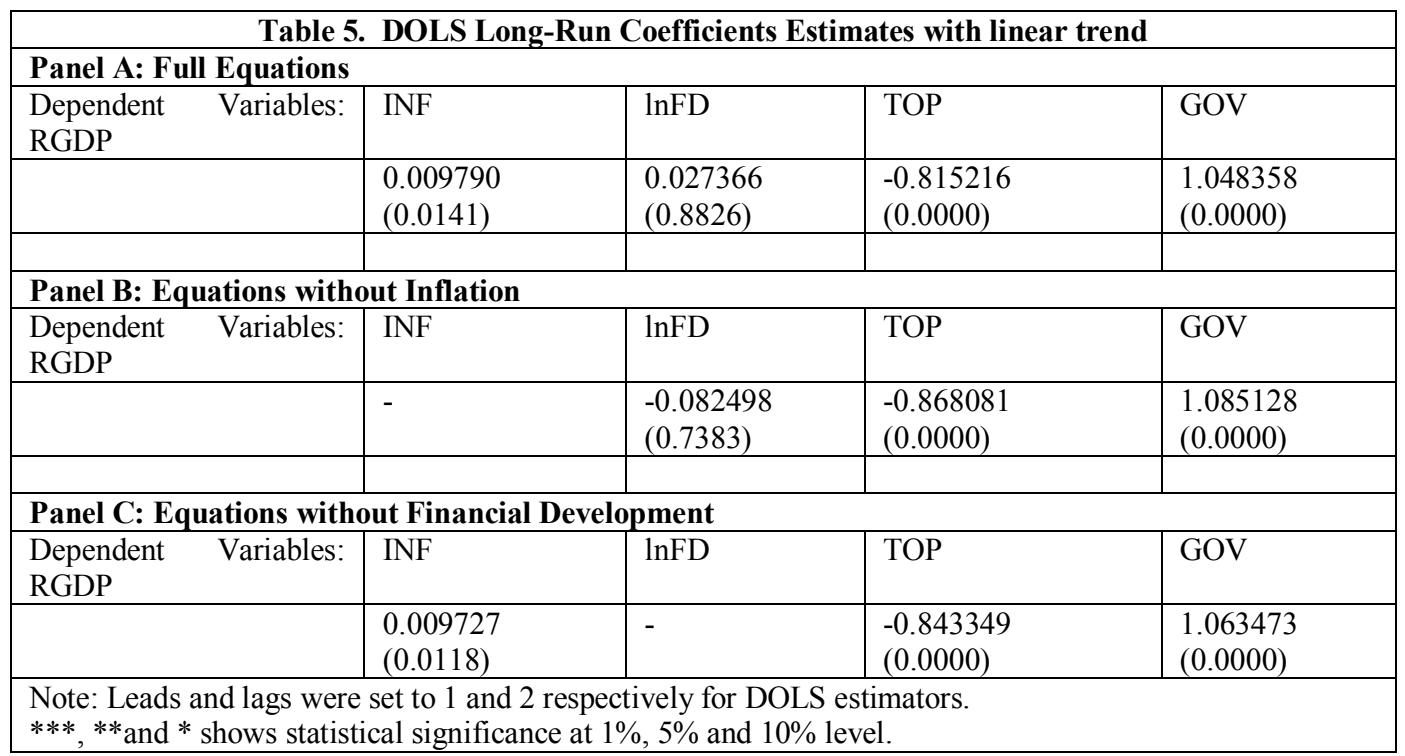

Panel A of Table 5, brings out the precise nature of the long-run relationship among the variables with Output as the dependent variable, the following inferences can be drawn: first, the coefficient of inflation is found to be positive and statistically significant indicating an increase in inflation in the long-run raises real output during the study period. Second, the long-run coefficient of financial development is found also to be positive but not statistically significant supporting the premise that financial intermediation promotes economic growth. Third, the estimated long-run coefficient of trade openness is negative and significant indicating that trade liberalization has a deleterious effect on economic growth. This might be due to the fact that Nigeria is a primary product producer and exporter. Finally, the result shows that government spending is not neutral to economic growth; rise in government expenditure will enhance output growth. The results from Panel B and Panel $\mathrm{C}$ give an indication that inflation effect on growth is independent of financial development while the financial development effect on growth is dependent of inflation.

The long run association established implies causality but it does not reveal the directions of causation amongthem in the model. Thus we proceedin our analysis by reporting in Table 6 the multivariate causalities among the economicgrowth (RGDP), inflation (INF), financial development (FD), trade openness (TOP) and government spending (GOV).

\begin{tabular}{|c|c|c|c|c|c|}
\hline \multicolumn{6}{|c|}{ Table 6: ECM Short Run Coefficient Estimates } \\
\hline & \multicolumn{5}{|c|}{ Dependent Variable } \\
\hline Regressors & $\triangle \mathrm{RGDP}$ & $\Delta \mathrm{INF}$ & $\Delta \mathrm{FD}$ & $\Delta \mathrm{TOP}$ & $\Delta \mathrm{GOV}$ \\
\hline Constant & $\begin{array}{l}0.1213 * * * \\
(0.0039)\end{array}$ & $\begin{array}{l}-2.7498 \\
(0.3715)\end{array}$ & $\begin{array}{l}0.0980 * * \\
(0.0164)\end{array}$ & $\begin{array}{l}0.1188 * * \\
(0.0189)\end{array}$ & $\begin{array}{l}0.0637 \\
(0.1816)\end{array}$ \\
\hline$\Delta \ln R G D P$ & - & $\begin{array}{l}15.1094 \\
(0.1260)\end{array}$ & $\begin{array}{l}-0.4195 * * * \\
(0.0010)\end{array}$ & $\begin{array}{l}-0.9574 * * * \\
(0.0000)\end{array}$ & $\begin{array}{l}0.5385^{* * *} \\
(0.0011)\end{array}$ \\
\hline$\Delta \operatorname{lnGOVT}$ & $\begin{array}{l}0.4856^{* * *} \\
(0.0007)\end{array}$ & $\begin{array}{l}-0.8202 \\
(0.9222)\end{array}$ & $\begin{array}{l}0.1850^{*} \\
(0.0994)\end{array}$ & $\begin{array}{l}0.6444 * * * \\
(0.0001)\end{array}$ & - \\
\hline$\triangle \mathrm{INFL}$ & $\begin{array}{l}0.0027 \\
(0.1849)\end{array}$ & - & $\begin{array}{l}0.0010 \\
(0.6037)\end{array}$ & $\begin{array}{l}0.0017 \\
(0.4773)\end{array}$ & $\begin{array}{l}-0.0003 \\
(0.8630)\end{array}$ \\
\hline$\triangle \ln T O P N$ & $\begin{array}{l}-0.7280 * * * \\
(0.0000)\end{array}$ & $\begin{array}{l}9.7535 \\
(0.2443)\end{array}$ & $\begin{array}{l}-0.4645 * * * \\
(0.0000)\end{array}$ & - & $\begin{array}{l}0.5679 * * * \\
(0.0000)\end{array}$ \\
\hline$\triangle \mathrm{FDCPS}$ & $\begin{array}{l}-0.5196 * * * \\
(0.0008)\end{array}$ & $\begin{array}{l}-1.5384 \\
(0.8949)\end{array}$ & - & $\begin{array}{l}-0.7742 * * * \\
(0.0000)\end{array}$ & $\begin{array}{l}0.4181^{* *} \\
(0.0190)\end{array}$ \\
\hline $\operatorname{Ecm}(-1)$ & $\begin{array}{l}-0.5214 * * * \\
(0.0008)\end{array}$ & $\begin{array}{l}-0.4985 * * * \\
(0.0017)\end{array}$ & $\begin{array}{l}-0.2421 * * \\
(0.0201) \\
\end{array}$ & $\begin{array}{l}-0.5349 * * * \\
(0.0007)\end{array}$ & $\begin{array}{l}-0.7191^{* * * *} \\
(0.0000)\end{array}$ \\
\hline \multicolumn{6}{|c|}{ p-value in bracket (); } \\
\hline
\end{tabular}


The ECMs of all the models confirm a long run relationship among the variables. Specifically from our main model, this implies that any deviations from the long-runequilibrium relationships in the Nigerian economy are mainly caused bythe changes in real GDP. The P-value of the error correction term coefficient shows that it is statistically significant at a $1 \%$ level, thus suggesting that output growth adjust to the explanatory variables and the coefficient of the lagged ECM is equal to -0.5214 for short run model implying that the deviation from the long-term equilibrium is corrected by about 53 percent over the following year. This means that the adjustment takes place very quickly.

We also found no evidence of short run causality between RGDP and INF; and there is existence of short runinteraction between RGDP and FD i.e., a bi-directional causalitybetween the variables. Many empirical studies (such as Guiso, Sapienza and Zingales, 2004; Levine, 2006; Demirguc-Kurt and Levine, 2001) have supported the view that an improved or developed financial system is able to promote high economicexpansion through technological changes, product and servicesinnovation, which in turn will create high demand on the financialservices and as the financial institutions effectivelyresponse to these demand, then these changes will stimulate a highereconomic achievement. Both financial and economic developmentstherefore are positively interdependent and their relationships could thenlead to bi-directional causality. However, the result of our main model reveals a negative interdependent between economic growth and financial development, which is in agreement with other findings such as Akinlo and Egbetunde (2010), Saibu, Nwosa, and Agbeluyi, (2011), Adusei (2012) and Okwo et al (2012.

\begin{tabular}{|l|l|l|l|l|l|}
\hline \multicolumn{7}{|l|}{ Table 7: Variance Decomposition } \\
\hline & Explained by Shocks in: & INF & lnGOV & lnTOP \\
\cline { 2 - 6 } & lnRGDP & lnFD & IN & 0.00 & 0.00 \\
\hline 1 & 100.00 & 0.00 & 0.05 & 0.16 & 0.10 \\
\hline 2 & 99.30 & 0.36 & 0.22 & 0.31 & 0.09 \\
\hline 3 & 98.69 & 0.65 & 0.42 & 0.46 & 0.08 \\
\hline 4 & 98.16 & 0.86 & 0.58 & 0.64 & 0.08 \\
\hline 5 & 97.69 & 0.98 & 0.69 & 0.84 & 0.11 \\
\hline 6 & 97.28 & 1.05 & 0.76 & 1.08 & 0.15 \\
\hline 7 & 96.91 & 1.07 & 0.78 & 1.35 & 0.22 \\
\hline 8 & 96.56 & 1.06 & 0.78 & 1.66 & 0.31 \\
\hline 9 & 96.19 & 1.03 & 0.77 & 1.99 & 0.41 \\
\hline 10 & 95.79 & 1.01 & & \\
\hline
\end{tabular}

The study further exploredthe dynamic interaction between financialdevelopment and economic growth by testing thevariance decompositions (VDCs) and impulse-response functions(IRFs) of the model. The results of VDCs is reported in Table 7 and it provides detailedinformation on the relative strength of the financial depth, share ofinvestment and inflation in explaining the changes in the economicgrowth. From the VDCs and IRFs results, we are also able to capturehe relative importance of various shocks and their influences onthe economic growth. The VDCs and IRFs are simulated byorthogonalizing the innovations in the vector autoregression (VAR)equations using the so-called Cholesky decomposition suggested bySim (1980) with the orderings of the variables: $\operatorname{lnRGDP}$, lnFD, INF, lnGOV and lnTOP.Based on VDCs results for the horizon of 1 to 12 periods, we findthat the variations in the economic growth in Nigeria respond moreto shocks in trade openness and next government spending. Thevariations in the economic growth in the country, however, rely moreon its own innovations. For instance in $10^{\text {th }}$ period, the result indicates that about 96 percent portion of economic growth is explained by its own innovative shocks while innovative shocks of financial development, inflation government expenditures and trade openness to economic growth is by 1.01 percent, 0.77 percent, 1.99 percent and 0.41 percent respectively.

The effect of financial development as measured by share of credit to private sector in GDP is low in the long run and negative in the short run as demonstrated (see Tables 5 and 6). This finding may be explained in line with the observations of Shen and Lee (2006) thatprovided evidence that only stock market development has positive effects ongrowth and that banking development has an unfavorable, if not negative, effect on growth.More so, Saci et al. (2009)following Levine et al. (2000), Rousseauand Wachtel (2000); Beck and Levine (2002) and Yao (2006) found that while the stock market variables in their model are positively and significantly related togrowth, the standard banking sector variables (credit tothe private sector and liquid liabilities) have negative effects on growth.

To complement our analysis on the VDCs, the study further generatedthe impulse response functions (IRFs). As reported in Figure 1, the overallresults seem to be very much consistent with our earlier findings.Economic growth seems to have immediate response to shocks in thefinancial depth and share of investment. This further implies that anypolicies pertaining to the price stability, investment and financialdevelopment should at least be noted by the government in order tospeed up their economic growth. 
Figure 1: Generalized Impulse-Responses Functions

Response of LOG_RGDP to LOG_RGDP

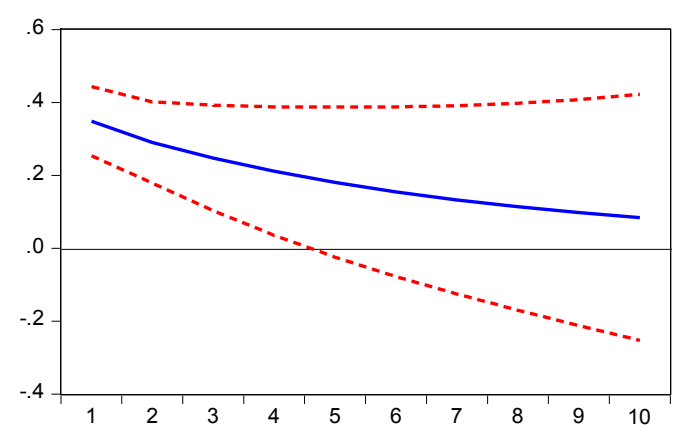

Response of LOG_RGDP to INF

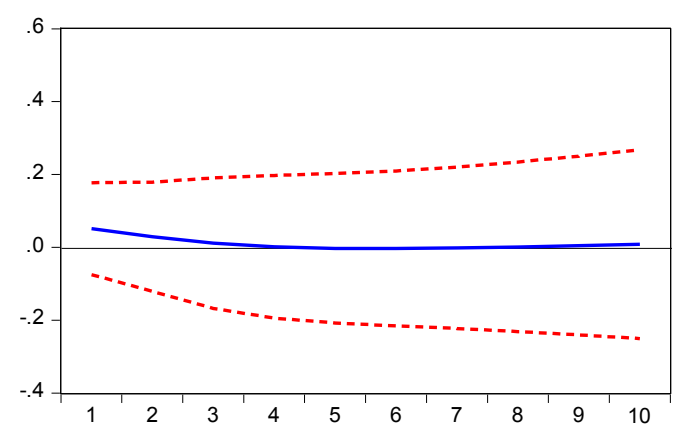

Response of LOG_RGDP to LOG_TOP

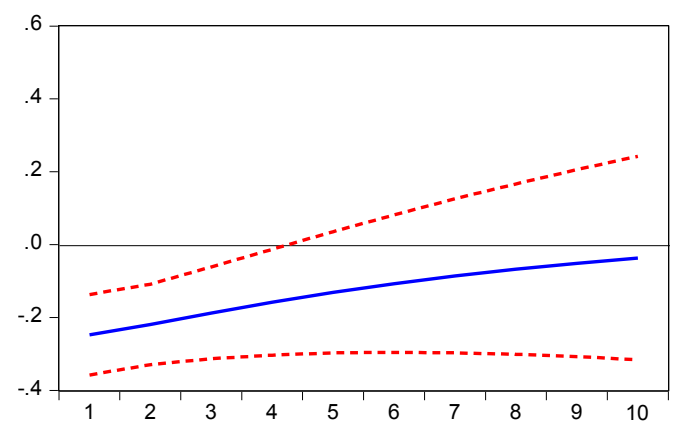

Response of LOG_RGDP to LOG_FD

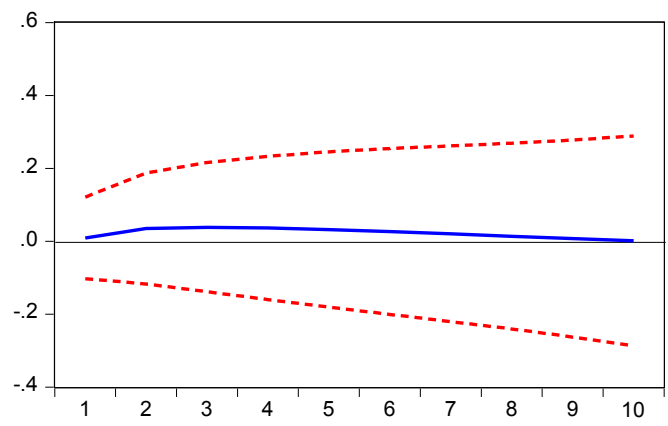

Response of LOG_RGDP to LOG_GOV

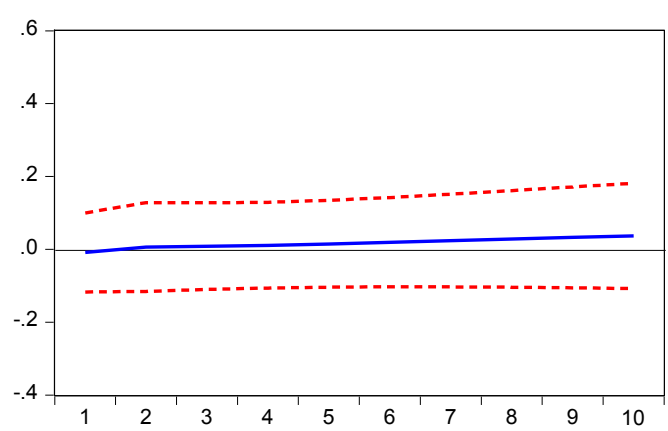

Finally, we have examined the stability of the long-run parameters together with the short-run movements for the equations. For test, the study relied on cumulative sum (CUSUM) and cumulative sum squares (CUSUMSQ) tests that were proposed by Borensztein, et al. (1998). The same procedure has been utilized by Pesaran and Pesaran (1997), Suleiman (2005) and Mohsen etal (2002) to test the stability of the long-run coefficients. The tests applied to the residuals of the ECM model.. 
Figure 2: Cumulative Sum of Recursive Residuals

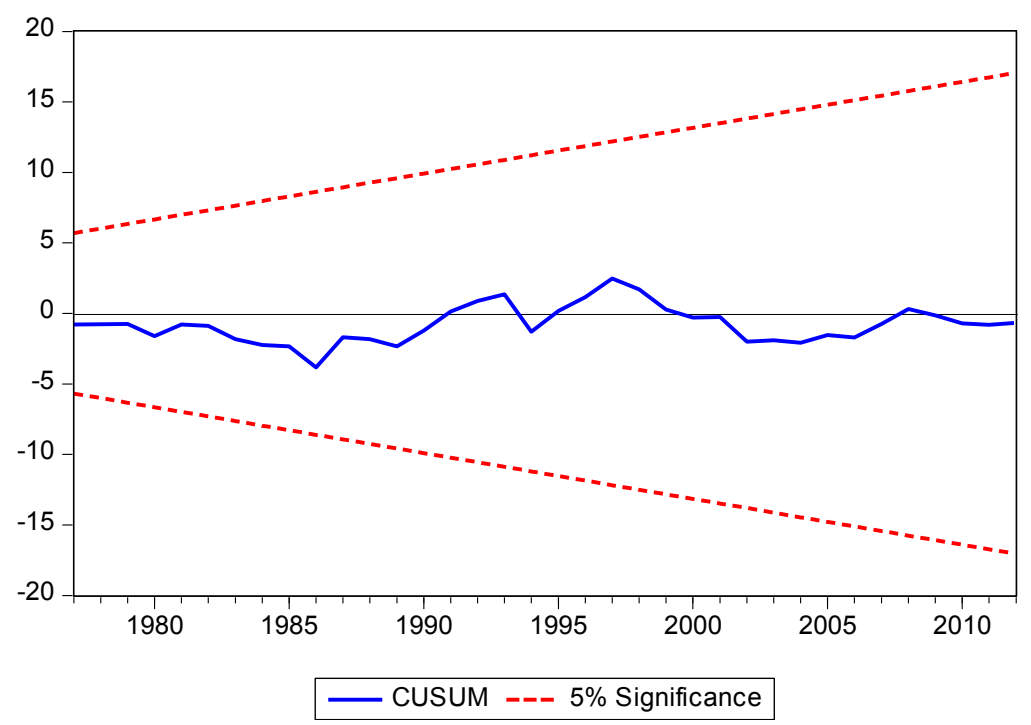

Figure 3: Plot of Cumulative Sum of Squares of Recursive Residuals

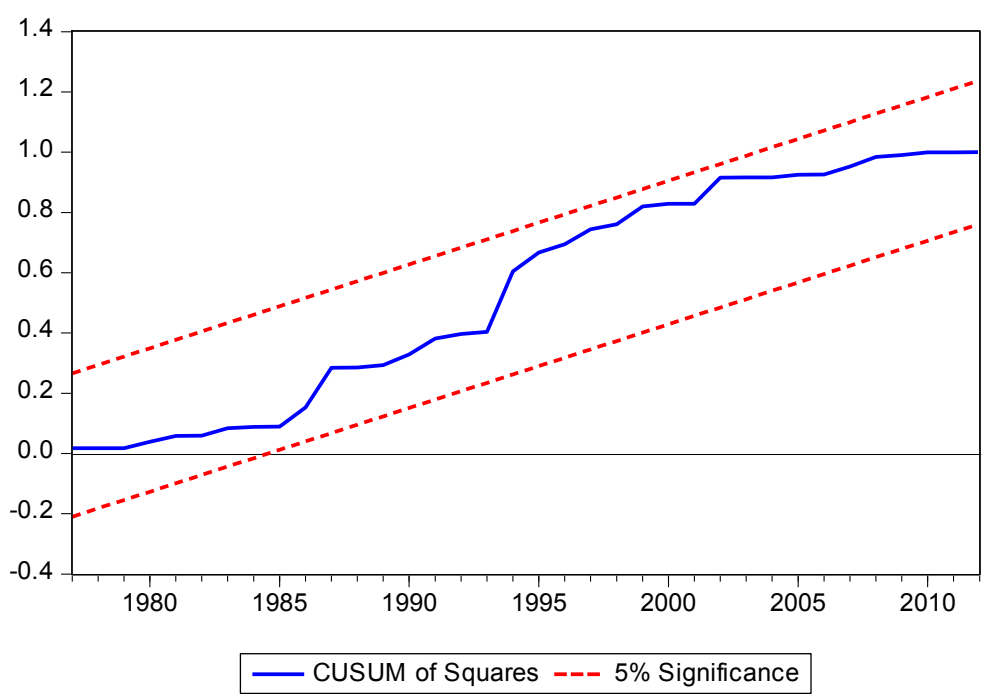

Figures 2 and 3 plot the CUSUM and CUSUM of squares statistics for Equation (6). It can be seen from both Figures that the plot of CUSUM and CUSUMSQ stay within the critical $5 \%$ bounds that confirm the long-run relationships between variables and also shows the stability of coefficient. Hence the model adopted in this study seems to be good enough and robust in estimating the short- and long-run relationships between financial development and economic growth.

\section{Summary, Conclusions and Policy Implications}

This study aimed at empirically exploring the triangle of relationships - finance-inflation-growth with the broader data that have been used in the recent empirical literature on growth and to see whether a direct effect of inflation on growth can be identified as well as an indirect effect through financial sector development. It attempts to investigate the finance-inflation-growth nexus using multivariate causality tests within a vector error correction model (VECM) and also seeks to explore the relative strength of the variables in affecting economic growth using the variance decompositions (VDCs) and the impulse-response functions (IRFs) based on the structural vector autoregression (VAR) framework. After studying the time-series properties of these variables for stationarity and cointegration, the study employed dynamic ordinary least square (DOLS) to estimate the long run relationship and investigate the causal relations among variables within the framework of ECM. We found that both Engel - Granger and Johansen cointegration test suggest that the variables are cointegrated. Based on the existence of cointegration relationship among the variables, we therefore estimate the long-run relationships using the Stock-Watson's dynamic ordinary least squares (DOLS) model. The results of 
DOLS model give an indication that inflation effect on growth is independent of financial development while the financial development effect on growth is dependent of inflation. Furthermore, we also found no evidence of short run causality between RGDP and INF; and there is existence of short run interaction between RGDP and FD that is a bi-directional causality between the variables. Variance decompositions (VDCs) results revealed the variations in the economic growth in Nigeria respond more to shocks in trade openness and next government spending, however, the variations in the economic growth rely more on its own innovations. The policy implication of this finding is for policy makers to develop strategy that will holistically reform the financial system and enhance stock market development along side with banking financial institutions. Finally, since financial development effect on growth is dependent of inflation, policy that will ensure price stability will promote output further.

\section{References}

[1]. Abd.Majid, M. Shabri (2007). Does Financial Development and Inflation Spur Economic Growth in Thailand? Chulalongkorn Journal of Economics 19(2), August: 161-184

[2]. Adelakun, O. J. (2010). Financial Sector Development and Economic Growth in Nigeria.International Journal of Economic Development Research and Investment Vol. 1, No 1: 25-41

[3]. Akinboade, O.A. (1998). Financial development and economic growth in Botswana: A Test For Causality. Savings and Development, 22(3), 331-348

[4]. Akinlo, A. E. andEgbetunde, T. (2010). Financial Development and Economic Growth: TheExperience of 10 Sub-Saharan African Countries Revisited. The Review of Finance and BankingVolume 02, Issue 1, Pages 017 - 028

[5]. Apergis, N., Filippidis, I., Economidou, C. (2007). Financial deepening and economic growth linkages: a panel data analysis. Review of World Economics, 143(1), 179-198

[6]. Asterio, D. and Price, S. (2007). Applied Econometrics', A Modern Approach. Basingstoke: Palgrave Macmillan.

[7]. Baba, Y., Hendry, D. F., \& Starr, R. M. (1992).The demand for m1 in the USA, 1960-1988.The Review of Economic Studies, 59, 25-61. http://dx.doi.org/10.2307/2297924

[8]. Bannerjee, A. V., Newman, A. F. (1998). Occupational Choice and the Process of Development.Journal of Political Economy, 101, 274-298.

[9]. Beck, T., and Levine, R. (2002). Stock markets, banks and growth: panel evidence. World Bank Working Paper.

[10]. Bittencourt, M. (2012). Financial development and economic growth in Latin America: is schumpeter right? Journal of Policy Modeling, 34(3), 341-355.

[11]. Blanco, L. (2009). "The Finance-Growth Link in Latin America”, Southern Economic Journal, 76(1):224-248.

[12]. Borensztein, E., de Gregorio, J. \& Lee, J-W. (1998). How Does Foreign Direct Investment Affect Economic Growth? Journal of International Economics, 1 (45), pp. 115-135

[13]. Chang, T. and Caudill, S.B. (2005). Financial Development and Economic Growth: the case of Taiwan. Applied Economics, 37(12): 1329-1335.

[14]. DeJong, D. N., Nankervis, J. C., Savin, N.E and C. H. Whiteman (1992).Integration versus trend stationarity in time series.Econometrica, 60, 423-433.

[15]. Dickey, D., and Fuller, W. (1979). Distribution Of The Estimators For Autoregressive Time Series With A Unit Root. Journal of the American Statistical Association, 74:427-731.

[16]. Elliot, G., Rothenberg, T. J., \& Stock, J. H. (1996).Efficient Tests for an Autoregressive Unit Root.Econometrica, 64, 813-36.

[17]. Engle, R. F. and Granger, C. W. J. (1987).Cointegration and error correction representation: estimation and testing. Econometrica, $55,251-276$.

[18]. Granger, C. W. J. and Newbold, P., (1974). Spurious regression in econometrics.Journal of Econometrics, 2, 111-120

[19]. Granger, C.W.J., (1988).Causality, Cointegration and Control.Journal of Economic Dynamics and Control, 12, 551-559

[20]. Gujarati, D.N (2006). Essential of Econometrics, 3rd Edition, McGraw Hill

[21]. Harris R and Sollis R. (2003).Applied Time Series Modelling and Forecasting.United Kingdom, Wiley.

[22]. Hurlin, C. and Venet, B. (2008). Financial Development and Growth: A re-examination using a panel Granger causality test. Working Paper Halshs-003199995_vl.

[23]. Idowu, K. O. (2005). A Preliminary Investigation into the Causal Relationship between Exports and Economic Growth in Nigeria.CBN Economic and Financial Review, 43(3),29-50.

[24]. Johansen, S. (1988). The Mathematical Structure of Error Correction Models.Comtemporary Mathematics, 80:359-386

[25]. Johansen, S. and Juselius, K. (1990).Maximum likelihood estimation and inference on cointegration with application to the demand for money.Oxford Bulletin of Economics and Statistics, 52, 169-210.

[26]. Levine, R., Loayza, N., Beck, T. (2000). Financial intermediation and growth: causality and causes. Journal of Monetary Economics, 46, 31-77

[27]. Michael Adusei (2012). Financial Development and Economic Growth: Is Schumpeter Right? British Journal of Economics, Management \& Trade 2(3): 265-278.

[28]. Mohsen, Bahmani-Oskooee, Ng R..W., (2002). Long Run Demand for Money in Hong Kong: An Application of the ARDL Model. International journal of business and economics, Vol. 1, No. 2, pp. 147-155.

[29]. Narayan, P.K. and Smyth, R. (2005). The residential demand for electricity in Australia: an application of the bounds testing approach to cointegration. Energy Policy 33, 457-464.

[30]. Ng, S., and P. Perron (2001). Lag Lenght Selection and the Construction of Unit Root Tests with Good Size and Power. Econometrica 69, 1519-1554.

[31]. Odeniran, S. O. and Udeaja, E.A (2012).Financial Sector Development and Economic Growth: EmpiricalEvidence from Nigeria. CBNEconomic and Financial Review Volume 48(3) September.

[32]. Odhiambo, N.M. (2004). Is financial development still a spur to economic growth? A causal evidence from South Africa. Savings and Development, 28, 47-62

[33]. Okwo, I. M., Eze, E. C. and Ugwunta, D. O. (2012). Does Financial Sector Development Cause Economic Growth? Empirical Evidence From Nigeria. International Journal of Current Research Vol. 4, Issue, 11, pp.343-349, November.

[34]. Peseran, M. H. and Peseran, B. (1997). Working with Microfit 4.0: Interactive Econometric Analysis. Oxford: Oxford University Press. 
[35]. Phillips P.C.B., Perron P. (1988). Testing for a unit root in a time series regression.Biometrika, 75, 335-346

[36]. Rahaman, M. M. and Salahuddin, M. (2010). The Determinants of Economics Growth in Pakistan: Does Stock Market Development Play a Major Role? Economic Issues, Vol. 15(2):69-86.

[37]. Rousseau, P.L., and Wachtel, P. (2000). Equity markets and growth: cross country evidence ontiming and outcomes, $1980-95$. Journal of Banking and Finance, 24, 1933-57

[38]. Rousseau, P.L., Vuthipadadorn, D. (2005). Finance, investment and growth: time series evidence from 10 Asian Economies. Journal of Macroeconomics, 27, 87-106

[39]. Saci, K., Giorgioni, G., and Holden, K. (2009). Does financial development affect growth? Applied Economics, 41, 1701-1707

[40]. Saibu, I.M.O., Nwosa, P. and Agbeluyi, A. M. (2011).Financial Development, Foreign Direct Investment and Economic Growth in Nigeria.Journal of Emerging Trends in Economics and Management Sciences (JETEMS) 2 (2): 146-154

[41]. Schumpeter J.A. (1911). The theory of economic development. Harvard University Press, Cambridge, MA.

[42]. Shen, C., and Lee, C. (2006).Same financial development yet different economic growth-why?Journal of Money, Credit and Banking, 38(7), 1907-1944

[43]. Sims, C.A. (1980). Macroeconomics and Reality.Econometrica, 48, 1-48

[44]. Stock, J. H., \& Watson, M. (1993). A simple estimator of cointegration vectors in higher order integrated systems. Econometrica, 61, 783-820. http://dx.doi.org/10.2307/2951763

[45]. Suleiman (2005). The Impact of Investment and Financial Intermediation on economic Growth: New Evidence from Jordan. Abstract mimeo.

[46]. Torruam, J.T., Chiawa, M.A. and Abur, C.C (2013). Financial Deepening and Economic Growth in Nigeria:an Application of Cointegration and Causality Analysis. 3rd International Conference on Intelligent Computational Systems (ICICS'2013) April 2930, 2013 Singapore

[47]. Ünalmiş, D. (2002). The Causality between Financial Development and Economic Growth.The Case of Turkey.Research Department, Central Bank of the Republic of Turkey, 06100,Ankara.

[48]. Wadud, M.A.(2005). Financial Development and Economic Growth: A Cointegration and ECM Approach for South Asian Countries. Paper presented at International Conference of the Asian Law and Economics Association at Seoul National University, South Korea on 24-25 June, 2005

[49]. Waqabaca, C. (2004). Financial development and economic growth in Fiji.Working Paper 2004/03.Economics Department Reserve Bank of Fiji.

[50]. Yao, S. (2006). On economic growth, FDI and exports in China.Applied Economics, 38,339-51. 